ЦИВІЛЬНЕ ПРАВО І ЦИВІЛЬНИЙ ПРОЦЕС;

СІМЕЙНЕ ПРАВО; МІЖНАРОДНЕ ПРИВАТНЕ ПРАВО

УДК 347.1:340.132(477)

DOI https://doi.org/10.32844/2618-1258.2019.5-2.7

ЗАВАЛЬНЮК С.В.

\title{
ПРОБЛЕМАТИКА СПІВВІДНОШЕННЯ ПОНЯТЬ «ПРОГАЛИНИ В ЦИВІЛЬНОМУ ЗАКОНОДАВСТВІ» ТА «ПРОГАЛИНИ В ЦИВІЛЬНОМУ ПРАВІ»
}

В юриспруденції науковці-правники часто використовують такі, на перший погляд, подібні поняття, як «прогалина в праві», «прогалина в законі» та «прогалина в законодавстві». Часто в науковій літературі можна побачити, що поняття «прогалини в праві» та «прогалини в законодавстві» науковцями не розрізняються. Для вірного визначення підстав і способу подолання прогалин цивільного законодавства необхідно розмежувати вищеназвані поняття.

Дослідження питання правової природи правових прогалин так чи інакше порушували М.І. Бару, Н.А. Гущина, О.М. Калашник, О.В. Колотова, В.В. Лазарев, В.М. Марчук, Ф.Р. Уранський, О.М. Ярошенко та багато інших. Однак більшість вказаних авторів, досліджуючи питання прогалин, майже завжди ототожнюють поняття «прогалини у праві» і «прогалини у законодавстві», через що в науковій доктрині наявна плутанина та велика кількість неточностей. Також більшість вказаних авторів зовсім не розглядали цивільно-правовий аспект поставленого питання, що надає цій статті ще більшої актуальності.

У статті визначається співвідношення понять «прогалини в цивільному праві» та «прогалини в цивільному законодавстві». Актуальність окреслених питань зумовлена тим, що, досліджуючи прогалини в праві, зокрема в цивільному праві, більшість науковців досліджували лише прогалини в законодавстві, але через нечіткість своєї позиції щодо розмежування цих двох понять вони ігнорували весь спектр можливих досліджень природи як прогалин у цивільному праві, так і прогалин у цивільному законодавстві, що зумовило відсутність дослідження всього можливого інструментарію, всіх способів подолання прогалин у цивільному законодавстві України. Отже, ця тематика потребує подальшого наукового опрацювання і ще буде зберігати актуальність у майбутньому. Дослідження в цій статті спрямоване на детальний розгляд підходів до розуміння зазначених понять, на визначення і детальне обгрунтування їх співвідношення.

Ключові слова: прогалина, прогалина в праві, прогалина в законодавстві, прогалина в циивільному праві, прогалина в цивільному законодавстві, прогалина в цивільному законодавстві Украӥни, прогалина в ичиільному законі.

In jurisprudence, legal scholars often use such, at first glance, similar concepts as a gap in law, a gap in law statute and a gap in legislation. Often in the scientific literature you can see that the concept of gaps in law and gaps in legislation scientists do not differ. To correctly determine the basis and method of overcoming the gaps in civil legislation, it is necessary to distinguish between the above concepts.

The research of the legal nature of legal gaps was raised in one way or another in their works: Baru M.I., Gushchina N.A., Kalashnik A.N., Kolotova A.V., Lazarev V.V., Marchuk V.N., Uransky F.R., Yaroshenko O.M. and many others. However, the vast majority of these authors, exploring the issue of gaps, almost always identify the concept of gaps in law and gaps in legislation, which is why there is confusion and a large number of inaccuracies in the scientific doctrine. Also, most of these authors did not consider the civil law aspect of the question at all, which makes this article even more relevant.

ЗАВАЛЬНЮК С.В. - кандидат юридичних наук, доцент кафедри цивільного права (Національний університет «Одеська юридична академія») 
The article defines the ratio of the concepts of gaps in civil law and gaps in the civil legislation of Ukraine. The relevance of these issues is due to the fact that when researching the gaps in law, and in particular in civil law, the vast majority of scientists studied only gaps in the legislation, but because of their vague position regarding the distinction between these two concepts, they ignored the whole range of possible studies of nature as gaps in civil law, and gaps in civil legislation, which led to the lack of research on all possible tools, all ways to overcome gaps in civil legislation of Ukraine. So, this topic requires further scientific processing and will still remain relevant in the future. The research in this article is aimed at a detailed review of existing approaches to understanding these concepts, at the definition and detailed justification of their relationship.

Key words: gap, gap law, gap in legislation, gap in civil law, gap in civil legislation, gap in the civil legislation of Ukraine, gap in the civil law, gap in statute.

Вступ. В юриспруденції науковці-правники часто використовують такі, на перший погляд, подібні поняття, як «прогалина в праві», «прогалина в законі» та «прогалина в законодавстві». Також в юридичній науковій літературі вживається синонім до слова «прогалина» - «лакуна» (від лат. Lacuna - заглиблення, порожнина), який зустрічається ще в Codex Theodosianus 438 p. $[18$, c. 44$]$. Для вірного визначення підстав і способу подолання прогалин цивільного законодавства необхідно розмежувати вищеназвані поняття.

Дослідження питання правової природи правових прогалин так чи інакше в своїх працях порушували М.I. Бару, Н.А. Гущина, О.М. Калашник, О.В. Колотова, В.В. Лазарев, В.М. Марчук, Ф.Р. Уранський, О.М. Ярошенко та багато інших. Однак більшість вказаних авторів, досліджуючи питання прогалин, майже завжди ототожнюють поняття «прогалини у праві» і «прогалини у законодавстві», через що в науковій доктрині наявна плутанина та велика кількість неточностей. Також більшість вказаних авторів зовсім не розглядали цивільно-правовий аспект поставленого питання, що надає цій статті більшої актуальності.

Постановка завдання. Метою статті $є$ визначення поняття «прогалини в цивільному законодавстві України» та «прогалини в цивільному праві», їх розмежування та дослідження їх співвідношення.

Результати дослідження. Відповідно до листа Міністерства юстиції «Щодо порядку застосування нормативно-правових актів у разі існування неузгодженості між підзаконними актами» вітчизняним законодавцем розрізняються прогалини в праві та прогалини в законі. Прогалини в праві - це повна або часткова відсутність у чинних нормативно-правових актах необхідних юридичних норм. Прогалини в законі - це повна або часткова відсутність необхідних юридичних норм у законі [10].

Якщо з розмежуванням прогалин у законі та праві проблем не виникає, то стосовно розмежування прогалин у законодавстві і праві в теорії права точиться гострий диспут. Один із багатьох вчених, хто ототожнює ці поняття, $є$ В.М. Марчук. Вчений вважає, що прогалина в праві $\epsilon$ тотожним поняттям прогалині в законодавстві, оскільки відсутні закон чи норми в законі, які б врегульовували конкретні життєві обставини чи відносини, з якими, своєю чергою, має справу правозастосовувач, якщо $є$ необхідність саме правового врегулювання таких життєвих обставин чи відносин [13].

Окремі вчені-правники з метою вказівки на відсутність правової норми, яка регулює певні життєві обставини чи відносини, використовують поняття «прогалина в законодавстві». Прикладом може слугувати визначення С.С. Алексеєва, за яким прогалина в законодавстві розглядається як повна або часткова відсутність правових норм у чинних законах [2, с. 118]. П.О. Недбайло визначає цей термін як прогалину у змісті чинного права (у випадку законодавчих норм) щодо фактів суспільного життя, які знаходяться у сфері правового регулювання [16, с. 456].

На думку П.М. Рабіновича, прогалина в законодавстві являє собою відсутність нормативно-правової регламентації певної групи суспільних відносин у сфері правового впливу, що окреслюється основними принципами права $[21$, с. 140]. О.Ф. Черданцев у дослідницькій діяльності оперує поняттям «прогалина у праві», яку визначає як відсутність норми права, що має бути у системі права з точки зору принципів та оцінок самого права, або інакше це така ситуація, коли виникає факт, що за своїм характером знаходиться у сфері правового регулювання та потребує правового рішення, однак норма права, що має його передбачати, - відсутня [28, с. 256]. 
3 точки зору А.С. Піголкіна, прогалини у праві - це прогалини у сфері фактичного правового регулювання, прогалини у системі чинного права, у межах суспільних відносин, врегульованих наявними законодавчими та іншими нормативними актами $[17$, с. 49$]$.

Сучасний стан розвитку теоретичної юриспруденції породив дискусію з питань розмежування понять «прогалина в праві» та «прогалина в законодавстві». Так, прихильником думки, що теоретично поняття «прогалина в праві» $€$ ширшим за «прогалину в законодавстві», залишається вітчизняний вчений С.П. Погребняк. Проте науковець припустив, що з урахуванням прийнятої нині системи джерел права, левову частину якого становить законодавство, здебільшого на практиці виявлення прогалин у законодавстві одночасно свідчить про наявність прогалини в праві $[18$, c. 45$]$.

I.A. Ісаєва вважає, що прогалини у праві є більш значущими, ніж прогалини в законодавстві. У другому випадку це питання юридичної техніки, в першому - причини можуть бути більш грунтовними [15, с. 35].

На думку Н.С. Караніна, поняття «прогалини» тлумачиться в теорії права 3 позицій легістської концепції праворозуміння (концепція праворозуміння, за якою ототожнюється право і закон): право розглядається як сукупність писаних норм і $є$ рівнозначним законодавству в широкому розумінні. Під самим терміном «прогалина в праві» швидше розуміється «прогалина в законі», оскільки він відображає відсутність норми права, що могла б відповідати на те чи інше питання [5].

Радянський дослідник законодавчих прогалин В.В. Лазарєв надає визначення поняттю «прогалини у праві», під яким пропонує розуміти повну або часткову відсутність нормативних приписів, потреба в яких виникає з еволюцією суспільних відносин і необхідністю вирішення конкретних питань на практиці за допомогою головних засад, сенсу і змісту чинного законодавства [7, с. 37]. Таким чином, В.В. Лазарєв фактично ототожнює поняття «прогалини в праві» i «прогалин у законодавстві» (використовуючи конструкцію «відсутність нормативних приписів» (установлений - рос.), виходячи з легістського радянського підходу до права, і навіть використовує їх як синоніми в процесі аналізу результатів судової практики.

Така думка знаходить своїх прихильників і нині. Як зазначає С.О. Погрібний, порівняння визначень прогалин у праві та у законодавстві свідчить про їхню схожість за суттю, i це невипадково. На думку науковця, прогалини, по суті, можуть бути лише в законодавстві [19, с. 14]. Це твердження $є$ спірним, адже воно звужує поняття права лише до нормативно-правових приписів, закріплених у законодавстві, і нівелює роль інших джерел (форм) права. Згідно з рішенням Конституційного Суду України, термін «законодавство» включає в себе закони України, чинні міжнародні договори України, згода на обов'язковість яких надана Верховною Радою України, а також постанови Верховної Ради України, укази Президента України, декрети і постанови Кабінету Міністрів України, прийняті в межах їх повноважень та відповідно до Конституції України і законів України [6]. Свідомо оминаючи дискусію стосовно поширення цього тлумачення на інші галузі права (крім трудового), включення до законодавства актів місцевого самоврядування, судової практики тощо, припустимо, що під законодавством маються на увазі всі писані приписи нормативних актів різного рівня і походження.

Однак, згідно з положеннями ч. 1 ст. 7 ЦК України, «цивільні відносини можуть регулюватися звичаєм, зокрема звичаєм ділового обороту. Звичай - правило поведінки, яке не встановлене актами цивільного законодавства, але є усталеним у певній сфері цивільних відносин» [27].

Тобто цілком можлива ситуація, що неврегульоване цивільним законодавством правовідношення одночасно врегульоване правовим звичаєм. Отже, має місце прогалина в законодавстві, проте у цьому випадку не буде прогалини у праві. Таким чином, звуження значення поняття «прогалини в праві» до відсутності в нормативно-правових актах норми права, а тим паче в контексті цивільно-правових відносин, є некоректним. Оскільки в багатьох випадках із великою вірогідністю можна говорити про наявність уявної прогалини в праві. У вказаному випадку застосування аналогії права чи аналогії закону було б неправильним, а звернення правозастосовного суб'єкта до принципів права порушувало б зазначену вище ч. 1 ст. 7 ЦК України.

Крім того, у разі такого підходу заперечується можливість договірного регулювання відносин, притаманного якнайбільше саме цивільному праву. Подібна теза $\epsilon$ провідною в сучасних дослідженнях правового регулювання, наприклад, договірних відносин [3], а отже, не може ігноруватися вченими-теоретиками і дослідниками в пов'язаних із цивільним правом галузях. На можливості використання цивільно-правового договору як засобу, що усуває ймовірність виникнення прогалин у цивільному законодавстві, заповнюючи їх у міру необхідності стосовно конкретних відносин, неодноразово наголошував Є.О. Харитонов [26, с. 78]. 
У науковій юридичній літературі є поширеною думка, що, враховуючи підходи природно-правової теорії права, прогалини у праві - неможливі, оскільки право виникає знизу й опосередковує потреби суспільства в регулюванні певних суспільних відносин [5]. У сучасних теоретичних дослідженнях так само висловлюються міркування, що термін «прогалина у праві» в буквальному розумінні сам пособі унеможливлює подолання прогалини у правозастосуванні шляхом використання ресурсів, які містяться в самому праві, оскільки це вказує на неможливість використання аналогії закону чи аналогії права [12, с. 213]. Однак ця теза викликала критику. Так, наприклад, С.П. Погребняк вважає ії загалом непереконливою і такою, що суперечить подальшому обгрунтуванню самих авторів тези [18, с. 45]. Вважаємо за необхідне приєднатися до думки С.П. Погребняка з цього питання.

На думку I.I. Полякова, проблемним $є$ саме поняття прогалини у зв'язку з різноманіттям підходів до розуміння права [24]. Якщо розглядати право загалом із точки зору природно-правової або соціологічної концепції, то воно безпрогалинне і досконале. У рамках цих підходів явище прогалинності може бути притаманне тільки позитивному праву. Якщо ж розглядати легістський підхід до праворозуміння, то оскільки відповідно до нього норма, що не закріплена в офіційному джерелі права, не може вважатися правовою, а відносини, врегульоване такою нормою, не є правовідносинами, прогалина в праві не може існувати в принципі [9, с. 174-176; 22, с. 163].

I.I. Поляков стверджує, що прогалина в позитивному праві, безперечно, є. Залежно від правової системи, в рамках якої це явище досліджується, прогалина може виникнути в різних джерелах позитивного права [8, с. 300-304]. 3 огляду на те, що основною офіційною формою права в Україні є нормативно-правовий акт, варто говорити про проблему прогалинності законодавства держави, актуальність якої визначається загальною кризою права України [20, с. 20].

Отже, I.I. Поляков, використовуючи легістський підхід до розуміння поняття права, фактично ототожнює поняття «прогалини в праві» і «прогалини в законодавстві». Навіть у подальшому у своїй праці він вбачає, що єдиним шляхом усунення прогалини в праві є прийняття відповідного нормативно-правового акта. При цьому особливого значення набувають досягнення юридичної науки [20, с. 20]. Високий рівень юридичної техніки покликаний забезпечити повноту ясність і логічність юридичних формулювань і законів загалом, тобто запобігти виникненню «початкових прогалин у законі» [8, с. 304]. Відображення в Законі виявлених або прогнозованих тенденцій розвитку правовідносин дає змогу знизити можливість появи «вторинних прогалин», пов'язаних із динамікою громадськості розвитку. Однак як би ефективно і юридично грамотно не працював законодавець, повністю уникнути прогалин неможливо [20, с. 20].

Ф.Р. Уранський виділив перелік авторів (В. Акімов, В.К. Забігайло, І.В. Михайлівський, П.Є. Недбайло та ін.), які стверджують, що прогалини в праві $є$ не що інше, як прогалини в законодавстві. Згідно з наведеною позицією, прогалини можуть виникнути лише у сфері суспільних відносинах, вже врегульованих правовими нормами [26, с. 112]. Характерним для цієї групи авторів є висловлювання П.Є. Недбайла: «Прогалина в праві - це фактична прогалина в законодавстві в сенсі відсутності конкретної норми для вирішення певних випадків, які перебувають у сфері впливу права» [16, с. 456]. Ще більш виразно висловлюється В.І. Акімов: «Сутність прогалини в праві полягає в неврегульованості конкретною нормою права відносин, які закріплені в його загальній нормі» [1, с. 110]. Варто додати, що під правовим регулюванням представники зазначеного підходу розуміють «фактичне правове регулювання, встановлене законодавством» [3, с. 11]. Необхідно зазначити, що такий підхід до прогалини в праві висловлювався правознавцями давно. Ще в XIX ст. I.В. Михайлівський визначав прогалину в праві як ситуацію, в якій «фактичні обставини випадку не відповідають жодній з описових частин (припущень) чинних юридичних норм» $[14$, с. 712$]$.

Через наведені висловлювання щодо прогалин у праві можна вивести поняття «прогалини в законодавстві», оскільки зазначені науковці також використовували легістський підхід. Сам Ф.Р. Уранський займався дослідженням прогалин у праві і розглядав зазначені твердження як вузький підхід до розуміння прогалин у праві, маючи на увазі під цим обсяг суспільних відносин, який потрапляє у сферу правового регулювання, в якому і здійснюється пошук прогалин. На його погляд, недоліком зазначеного підходу $є$ те, що він суттєво звужує ставлення до аналізованого правового явища, оскільки, грунтуючись на обмежено-позитивістському розумінні права, ототожнює два несумісних явища - право в широкому сенсі і закон як форму вираження права $[25$, с. 113$]$. За межами розгляду при цьому фактично залишаються всі відносини, які вже виникли через безперервний розвиток самого суспільства, але з тих чи інших причин ще не охоплені увагою законодавця. Звісно ж, що в рамках подібного підходу взагалі не можна говорити про можли- 
вість еволюційного розвитку правових систем. Крім того, як справедливо зауважує В.В. Лазарєв [9, с. 6-7], в разі повного ототожнення сфери правового регулювання з тією частиною суспільних відносин, яка охоплена чинним законодавством, неможливо обгрунтувати рішення юридичного спору з аналогії права, бо в цій ситуації може йтися тільки про аналогію закону.

Доволі добре описує правову природу прогалин у праві і прогалин у законі А.М. Майданюк, на підставі чого можна також зробити висновки щодо співвідношення цих двох понять. Науковець розрізняє поняття «прогалини в праві» $\mathrm{i}$ «прогалини в законі», але з використанням легістського підходу до поняття «прогалини в праві» їх розмежування не має чіткого вигляду. Під прогалиною в праві вона пропонує розуміти повну або часткову відсутність правових норм у чинних нормативних актах (що $€$ ширшим поняттям, ніж закон), яких потребує врегулювання конкретних життєвих обставин, правовідносин. Своєю чергою, під прогалиною в законі вона розуміє повну або часткову відсутність правових норм у певному законі, які необхідні для врегулювання правовідносин [11, с. 46]. На її думку, прогалини в праві зумовлені тим, що норми права однакової сили суперечать одна одній і тим самим знищують одна одну, оскільки без застосування способів подолання прогалин неможливо врегулювати правовідносини $[11$, с. 45].

Один із небагатьох дослідників, хто чітко розмежовує прогалини в праві і прогалини в законодавстві, - це Тарануха В. В її баченні право як об'єктивна категорія визначає і врегульовує лише певний стан суспільних відносин. Це пояснюється тим, що правотворчість є складним тривалим і формалізованим процесом. Тому яка б правова система не була досконалою, законодавець часто не має змоги швидко відреагувати на зміни у регулюванні суспільних відносин і не завжди може передбачити всі життєві обставини, які потребують правового регулювання. Враховуючи наведене, В. Тарнауха підтверджує, що прогалина в праві являє собою відсутність правових норм або їх частини, необхідних для врегулювання певних життєвих обставин, суспільних відносин, які мали і могли б бути врегульованими за допомогою права [23, с. 16-17].

Своєю чергою, В. Тарнауха визначає прогалину в законодавстві як відсутність нормативної правової регламентації конкретної групи суспільних відносин у галузі правового регулювання, які визначені головними засадами права, інакше кажучи, це відсутність норми права, що могла б врегулювати певний вид суспільних відносин, яким необхідне правове врегулювання [23, с. 17]. Такі прогалини мусять бути усуненими, проте, на думку науковця, це можливо лише шляхом здійснення правотворчого процесу, в ході прийняття нових нормативно-правових актів чи внесення змін і доповнень до нормативно-правових актів, що вже існують. Оскільки правотворчість $є$ тривалим процесом, усунення прогалин не може бути швидким, тому необхідне подолання прогалин за допомогою аналогій.

Висновки. Враховуючи все вищенаведене, можна помітити, що більшість дослідників прогалин у праві і прогалин у законодавстві ототожнюють ці два поняття, оскільки вони використовують легістський підхід до розуміння поняття «право», а відповідно, і прогалини в праві. Так, у більшості досліджень прогалин у праві, зокрема в цивільному праві, науковці-юристи досліджували саме відсутність нормативно-правового врегулювання правовідносин, ігноруючи той факт, що право у своєму зовнішньому прояві виражається не лише в формі нормативно-правових актах, але й у формі інших джерел (цивільно-правовий договір, правовий звичай), і чимало вчених-юристів у працях не обмежуються перерахованими джерелами права у главі 1 ЦК України. I тому на підставі викладеного варто чітко розмежувати ці два поняття і визначити прогалини в цивільному праві як ширше поняття щодо поняття прогалини в цивільному законодавстві. Тому з всіх запропонованих визначень можна виділити таке співвідношення: прогалина в цивільному законодавстві представляє собою відсутність нормативного врегулювання відносин, що виражається у відсутності належної норми в законодавстві, а саме в актах цивільного законодавства та міжнародних договорах, які регулюють цивільні правовідносини та згода на обов'язковість яких надана Верховною Радою України. В той час як прогалина в праві $\epsilon$ ширшим поняттям, вона може представляти собою відсутність такої норми в цивільно-правовому договорі, звичаї, судовій практиці або навіть відсутність такої ідеї чи концепції вираженої в науковій доктрині чи Римському праві тощо.

Таким чином, досліджуючи прогалини в праві, зокрема в цивільному праві, більшість науковців досліджували лише прогалини в законодавстві, але через нечіткість своєї позиції щодо розмежування цих двох понять вони ігнорували весь спектр можливих досліджень природи як прогалин у цивільному праві, так і прогалин у цивільному законодавстві, що зумовило відсутність дослідження всього можливого інструментарію способів подолання прогалин у цивільному законодавстві України. Отже, ця тематика потребує подальшого наукового опрацювання зберігатиме актуальність у майбутньому. 


\section{Список використаних джерел:}

1. Акимов В.И. Понятие пробела в праве. Правоведение. 1969. № 3. С. 110-113.

2. Алексеев С.С. Право: азбука - теория - философия: Опыт комплексного исследования. Москва : Статут, 1999. $712 \mathrm{c.}$

3. Блащук Т.В. Джерела правового регулювання договірних відносин: теоретико-правовий аспект. Часопис Наџіонального університету «Острозька академія». Серія «Право». 2013. № 1(7). URL: http://lj.oa.edu.ua/articles/2013/n1/13btvtpa.pdf. 1974. $135 \mathrm{c}$

4. Забигайло В.К. Проблема «пробелов в праве»: К критике буржуазной теории. Киев,

5. Каранина Н.С. Проблемные вопросы применения закона по аналогии. Актуальныле проблемы юридической науки и правоприменительной практики. Киров, 2007. Ч. 1. С. 36-40.

6. Керимов Д.А. Методология права (предмет, функции, проблемы философии права). Москва : Аванта,+ 2001.560 с.

7. Лазарев В.В. Пробелы в праве и пути их устранения. Москва : Юрид. л-ра, 1974. 184 с.

8. Лазарєв В.В. Загальна теорія права і держави. Москва : МАУП, 2000. 517 с.

9. Лазарєв В.В. Політичні аспекти проблеми заповнення прогалин в законодавстві. Проблеми політичних наук. Москва : Наука, 1980. С. 173-178.

10. Лист Міністерства юстиції «Щодо порядку застосування нормативно-правових актів у разі існування неузгодженості між підзаконними актами» від 30.01.2009 р. № H-35267-18. Oфiиіийний веб-сайт Верховної Ради Украӥни. URL: http://zakon4.rada.gov.ua/laws/show/v3526323-09

11. Майданюк A.M. Прогалини в законодавстві та шляхи їх усунення на сучасному етапі розвитку права. Наше право : Спецііалізоване видання. 2012. № 3, ч. 1. С. 45-50.

12. Малишев Б.В. Застосування норм права (теорія і практика) / Б.В. Малишев, О.В. Москалюк; за заг. ред. Б.В. Малишева. Київ : Реферат, 2010. 260 с.

13. Марчук В.М. Нариси з теорії права : навч. посібник / В.М. Марчук, Л.В. Ніколаєва. Київ : Істина, 2004. 304 с.

14. Михайловский И.В. Очерки философии права. Хропанюк В.Н. Теория государства и права: Хрестоматия. Москва, 1998. С. 712.

15. Науково-практичний коментар до цивільного законодавства України : у 2 т. В.Г. Ротань [та ін.] ; відп. ред. В.Г. Ротань. 2-е вид. Харків : Фактор, 2010. Т. 1. 800 с.

16. Недбайло П.Е. Применение советских правовых норм. Москва: Госюриздат, 1960.511 с.

17. Пиголкин А.С. Обнаружение и преодоление пробелов права. Советское государство и право. 1970. № 3. С. 49-57.

18. Погребняк С. Прогалини в законодавстві та засоби їх подолання Національного. Bicник Національного університету «Юридична академія України імені Ярослава Мудрого». 2013. № 1(72). С. 44-56.

19. Погрібний С. Аналогія закону та аналогія права як засоби регулювання договірних цивільних відносин. Теорія і практика інтелектуальної власності. 2010. № 5. С. 14-21.

20. Поляков, И.И. Пробема пробелов в законодательстве Украины. Правовые проблемы развития современной Украины : материалы межвуз. науч.-практ. конф., май 2004 г. 2005. С. 19-22.

21. Рабінович П.М. Основи загальної теорії права та держави : навч. посібник. Вид. 5-те, зі змінами. Київ : Атіка, 2001. 176 с.

22. Сулейманов Ф.М. Про прогалини і колізії в праві як джерела юридичних конфліктів : автореф. дис. ... канд. юрид. наук. Тбілісі, 1998. 35 с.

23. Тарануха В. Прогалини в праві: поняття, сутність, способи їх усунення та подолання. Юридична Украӥна : Щомісячний правовий часопис. 2009. № 2. С. 15-19.

24. Тиунова Л.Б. Плюрализм интересов и правопонимания. Правоведение. 1990. № 1.

25. Уранский Ф.Р. К вопросу о понятии и видах пробелов в праве. Вестник Московского университета. Сер. 11: Право. 2005. № 5. С. 111-121.

26. Харитонов $\mathrm{C}$. «Прогалини» у цивільному законодавстві: хиби правотворчості чи прийом законодавчої техніки. Юридичний вісник. 2013. № 1. С. 72-81.

27. Цивільний кодекс України від 16.01.2003 р. № 435-IV. Офіційний вебсайт Верховної Ради України. URL: http://zakon4.rada.gov.ua/laws/show/435-15

28. Черданцев А.Ф. Теория государства и права : учебник. Москва : Юрайт, 1999. 432 с. 